\title{
GAPPS - Gastric Adenocarcinoma and Proximal Polyposis of the Stomach Syndrome in 8 Families Tested at Masaryk Memorial Cancer Institute - Prevention and Prophylactic Gastrectomies
}

\author{
GAPPS - syndrom adenokarcinomu žaludku a mnohočetné \\ polypózy žaludku v 8 rodinách testovaných v Masarykově \\ onkologickém ústavu - prevence vč. profylaktické gastrektomie
}

Foretova L. ${ }^{1}$, Navratilova M. ${ }^{1}$, Svoboda M. ${ }^{1,2}$, Grell P. ${ }^{2}$, Nemec L. ${ }^{3}$, Sirotek L. ${ }^{3}$, Obermannova R. ${ }^{2}$, Novotny I. ${ }^{4}$, Sachlova M. ${ }^{4}$, Fabian P.5 , Kroupa R. ${ }^{6}$, Vasickova P. ${ }^{1}$, Hazova J. ${ }^{1}$, Stahlova Hrabincova E. ', Machackova E. ${ }^{1}$

\author{
' Department of Cancer Epidemiology and Genetics, Masaryk Memorial Cancer Institute, Brno \\ ${ }^{2}$ Clinic of Comprehensive Cancer Care, Masaryk Memorial Cancer Institute, Brno \\ ${ }^{3}$ Clinic of Surgical Oncology, Masaryk Memorial Cancer Institute, Brno \\ ${ }^{4}$ Department of Gastroenterology and Digestive Endoscopy, Masaryk Memorial Cancer Institute, Brno \\ ${ }^{5}$ Department of Oncology and Experimental Pathology, Masaryk Memorial Cancer Institute, Brno \\ ${ }^{6}$ Clinic of Internal Medicine and Gastroenterology, Faculty of Medicine, Masaryk University and University Hospital, Brno
}

\section{Summary}

Gastric adenocarcinoma and proximal polyposis of the stomach (GAPPS) is a rare variant of familial adenomatous polyposis. It is an autosomal-dominant cancer-predisposition syndrome with massive polyposis of the stomach and a significant risk of gastric adenocarcinoma. Li et al., 2016, described point mutations in the Ying Yang 1 binding site of the APC gene 1B promoter associated with GAPPS syndrome. The first GAPPS syndrome in a Czech family was described in 2016. At Masaryk Memorial Cancer Institute, GAPPS syndrome was diagnosed in eight families using Sanger sequencing. In all families, one mutation in promoter $1 \mathrm{~B}$ of $A P C$ gene NM_001127511: C.-191T>C was detected. This mutation was not found in any patient with multiple colon polyposis without a detected classic mutation in the APC gene. In total, 24 carriers of this mutation in promoter $1 \mathrm{~B}$ of the $A P C$ gene were detected. Out of those 24 carriers, 20 had massive gastric polyposis with more than 100 fundic glandular polyps diagnosed between the age of 22 and 65, 5 had already died of adenocarcinoma of the stomach (at the ages of $29,40,59,60$ and 64, respectively) and another woman was treated at the age of 29. Two female carriers do not yet have polyposis of the stomach at the ages of 31 and 65 , respectively; one female carrier has incipient polyposis at the age of 58. A male carrier does not have any clinical symptoms, gastroscopy was not indicated because of his age. Prophylactic total gastrectomy with D2 lymphadenectomy has already been performed 6 times at Masaryk Memorial Cancer Institute, in 5 cases without adenocarcinoma at the ages of 27, 34, 44, 51 and 66, respectively; in one female carrier adenocarcinoma of the stomach was detected in a histology specimen. Two prophylactic gastrectomies with D1 lymphadenectomy were performed at University Hospital Brno at the ages of 42 and 50, respectively. In the Czech Republic point mutation c.-191T >C (rs879253783) in the 1B promoter of the APC gene is a frequent cause of gastric polyposis with a high risk of gastric adenocarcinoma, even at a young age. Positively tested individuals are recommended to high-risk oncology clinic. A necessary part of the discussion with the patient is information about a preventive gastrectomy.

Key words

polyposis - gastric - hereditary - gastric cancer - gastrectomy
Supported by the grant project of the Czech Ministry of Health - RVO (MOÚ, 00209805).

Podpořeno grantem Ministerstva zdravotnictví RVO (MOÚ, 00209805)

The authors declare they have no potential conflicts of interest concerning drugs, products, or services used in the study.

Autor̆i deklarují, že $v$ souvislosti s předmětem studie nemaji žádné komerční zájmy.

The Editorial Board declares that the manuscript met the ICMJE recommendation for biomedical papers.

Redakční rada potvrzuje, že rukopis práce splnil ICMJE kritéria pro publikace zasílané do biomedicínských časopisů.

doc. MUDr. Lenka Foretová, Ph.D. Department of Cancer Epidemiology and Genetics Masaryk Memorial Cancer Institute Zluty kopec 7, 65653 Brno e-mail: foretova@mou.cz

Submitted/Obdrženo: 12. 3. 2019 Accepted/Přijato: 16. 4. 2019

doi: $10.14735 / a m k o 2019 S 109$ 


\section{Souhrn}

Syndrom adenokarcinomu žaludku a mnohočetné polypózy žaludku (GAPPS) je variantou syndromu familiární adenomatózní polypózy. Jedná se o autozomálně dominantně dědičný syndrom nádorové predispozice $s$ časně se vyvíjející masivní polypózou žaludku, lokalizovanou ve fundu a těle žaludku, nikoliv v antru, s vysokým rizikem vzniku adenokarcinomu. V roce 2016 Li et al publikovali výsledky výzkumu, kde zjistili, že bodové mutace v oblasti Ying Yang 1 vazebného místa 1B promotoru APC genu jsou zodpovědné za asociaci s GAPPS př́znaky. Tato regulační oblast většinou není zahrnuta v panelech pro masivní paralelní sekvenování a je nutné ji dovyšetřit Sangerovým sekvenováním. První údaje o rodině s GAPPS v České republice byly publikovány v roce 2016. V Masarykově onkologickém ústavu bylo zachyceno osm rodin s výskytem dědičného syndromu GAPPS. U všech rodin byla zjištěna jedna patogenní mutace v promotoru 1B APC genu, NM_001127511: C.-191T>C. Tato mutace nebyla nalezena u žádného pacienta s mnohočetnou polypózou tlustého střeva bez zjištěné klasické mutace $v$ genu $A P C$. Celkem bylo diagnostikováno 24 osob nosičů této mutace v promotoru 1B APC genu. Z těchto 24 osob mělo 20 nosičů masivní polypózu žaludku s více než 100 fundickými glandulárními polypy diagnostikovanou ve věku od 22 do 65 let, 5 již zemřelo na adenokarcinom žaludku (ve věku 29, 40, 59, 60 a 64 let), další žena ve věku 29 let se léčila. Dvě nosičky mutace ve věku 31 a 65 let zatím nemají vyvinutou polypózu žaludku, u jedné ve věku 58 let je incipientní polypóza žaludku. Nosič mutace nemá žádné klinické př́iznaky, gastroskopie nebyla vzhledem k věku indikována. Preventivní totální gastrektomie s D2 lymfadenektomií byla provedena $6 \times$ v Masarykově onkologickém ústavu, v 5 př́padech bez nálezu adenokarcinomu ve věku $27,34,44,51,66$, u jedné nosičky mutace byl ve věku 29 let nalezen $G 2$ adenokarcinom žaludku v histologickém preparátu. Další dvě profylaktické gastrektomie s D1 lymfadenektomií byly provedeny ve Fakultní nemocnici Brno u nosičů ve věku 42 a 50 let. Bodová mutace c.-191T>C (rs879253783) v 1B promotoru APC genu je v České republice častou př́činou polypózy žaludku a nese vysoké riziko adenokarcinomu žaludku i v mladém věku. Pozitivně testovaní pacienti jsou dispenzarizováni v rizikové onkologické ambulanci. Nezbytnou součástí diskuze s pacientem je informace o preventivní gastrektomii.

\section{Klíčová slova}

polypóza - žaludek - hereditární - karcinom žaludku - gastrektomie

\section{Introduction}

Gastric polyps are found in $1-4 \%$ of patients undergoing gastroscopy. Fundic gland polyps (FGP) are the most frequent and account for about $70 \%$ of all gastric polyps [1]. Sporadic FGPs are mostly seen in the gastric body and fundus, are smaller than $5 \mathrm{~mm}$ and are usually fewer in number (less than 10). These polyps are often caused by prolonged treatment of proton pump inhibitors (PPI) and are negatively associated with Helicobacter pylori infection. FGPs are mostly sporadic but may be seen in hereditary cancer syndromes like familial adenomatous polyposis (FAP), Lynch syndrome, Cowden syndrome, juvenile polyposis, Peutz-Jeghers syndrome and $\mathrm{MYH}$-associated polyposis with a variable risk of gastric cancer.

The polyps in these syndromes may differ histologically from purely dysplastic fundic polyps $[2,3]$. Syndrome polyps may be transformed into malignancy more frequently than sporadic.

A new autosomal dominant syndrome with multiple proximal polyposis of the stomach localised to the fundus and body, sparing the antrum and duodenum, with a high tendency to malignancy and adenocarcinoma of the stomach (gastric adenocarcinoma and proximal polyposis of the stomach
(GAPPS) syndrome) was described clinically in the year 2012 [1]. In 2016 Li et al. [4] published their research results in which they discovered that three point mutations located within the Ying Yang 1 (YY1) binding motif of promoter $1 \mathrm{~B}$ of the APC gene are responsible for association with GAPPS symptoms. This regulation region is usually not included in new generation sequencing (NGS) panels and must be resolved using Sanger sequencing. In six families three different mutations within the $Y Y 1$ region were found in the $A P C 1 \mathrm{~B}$ promoter: c. $-195 A>C$, c. -191 T>C, c. $-192 A>G$. The first family with GAPPS in the Czech Republic with the presence of the C. $-191 \mathrm{~T}>\mathrm{C}$ mutation was published in 2016 [5], in Austria in 2017 [6] and in Japan in 2018 [7]. YY1 is a ubiquitously expressed transcription factor that has multiple roles in oncogenesis and can act as an activator and repressor of transcription. [4]. During in vivo functional analysis with GAPPS segregating variants (c. $-195 A>C$, C. $-191 T>C$ and c. $-192 A>G$ ) each of them showed disruption of the YY1 transcription factor binding site and a significant decrease in transcription activity from the $1 \mathrm{~B}$ promoter compared to the wild-type construct [4]. In the majority of GAPPS polyps, the second hit in the form of loss of the wild- type allele or by somatic truncating mutations was seen. These events, however, are probably late in the development of gland polyps. APC haploinsufficiency may be responsible for polyposis, the second intervention with the removal of the second copy of the gene may be important for the development of dysplasia. According to Hosoya et al. [8] the $1 \mathrm{~B} A P C$ gene promoter in the gastric mucosa is about 15 times more transcribed than the $1 \mathrm{~A}$ promoter. Promoter $1 \mathrm{~A}$ is mostly methylated in gastric cancer cell lines, $97.5 \%$ non-tumour gastric mucosa and $82.5 \%$ of gastric carcinomas. Thus, promoter $1 \mathrm{~B}$ and its transcripts are very important in the gastric mucosa, the intestinal mucosa (colon) is protected primarily by the expression of isoforms from promoter $1 \mathrm{~A}$ (the main transcripts NM_000038.5; NM_001127510). Several $A P C$ isoforms are expressed from the 1B promoter; in the case of transcript NM_001127511 exons 2 and 7 are missing (in comparison with RefSeq NM_000038.5). Mutations in exon 2 and 7 lead to a milder form of FAP. Large deletions of the promoter $1 \mathrm{~B}$ region may lead to the deletion of the enhancers of promoters $1 \mathrm{~A}$ and $\mathrm{B}$ and cause intestinal polyposis with (though not always) FGP. Only two point mutations in the $1 B$ promoter caused intestinal polyposis, 
others caused only isolated polyposis of the stomach.

In the Department of Cancer Epidemiology and Genetics of the Masaryk Memorial Cancer Institute (MMCl), families with gastric cancer and/or gastric polyposis with or without colon polyposis were tested over several years. In all of these patients, testing for the $A P C$, MUTYH, genes for Lynch syndrome and other polyposis syndromes was negative. In 2017, we retroactively tested 25 of these patients for the possibility of GAPPS syndrome. In addition, 18 newly diagnosed patients with massive gastric polyposis/gastric cancer were tested.

\section{Methods}

In all patients, Sanger sequencing was used. Polymerase chain reaction amplification of the APC gene promoter 1 beta (5'UTR region; primers according to Li et al., 2016 [4] and sequencing at the 3130 Genetic Analyser (Applied Biosystems, ThermoFisher Scientific, USA) was performed. In all patients who tested positive, substitution in the APC gene (NM_001127511.2): C.-191T>C (rs879253783; genomic position: Chr5(GRCh38): g.112707527T>C; in case of RefSeq NM_000038.5(APC): c. $-30417 T>C$ ) was detected. The muta-

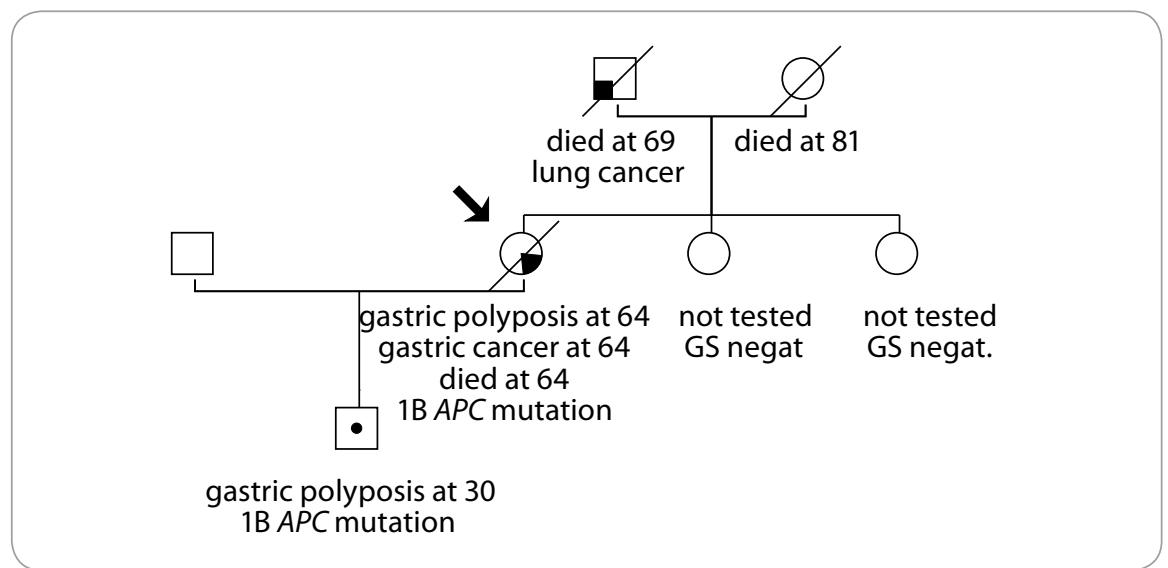

Fig. 1. Pedigree of family no. 1 (Masaryk Memorial Cancer Institute). GS - gastroscopy

tion was confirmed from the second isolated DNA sample.

\section{Results and families}

In eight families from the South Moravian region of the Czech Republic, a diagnosis of GAPPS syndrome was confirmed. Both patients with massive gastric polyposis and patients with gastric cancer were tested. All of the patients signed informed consent for molecular genetic testing; in those patients already deceased, the consent form was signed at the time of their first testing including consent to the use of the sample for re- search. For all living individuals, genetic counselling was performed before and after the testing.

\section{Family 1 (Fig. 1)}

An index case was diagnosed with massive stomach polyposis and with stomach adenocarcinoma at the metastatic stage at the age of 64 , she died within 3 months. She did not have a colonoscopy. The patient had been using PPI for more than 10 years but she was not monitored for gastroscopy during treatment. Her son was diagnosed with massive gastric polyposis at the age of 30 ,

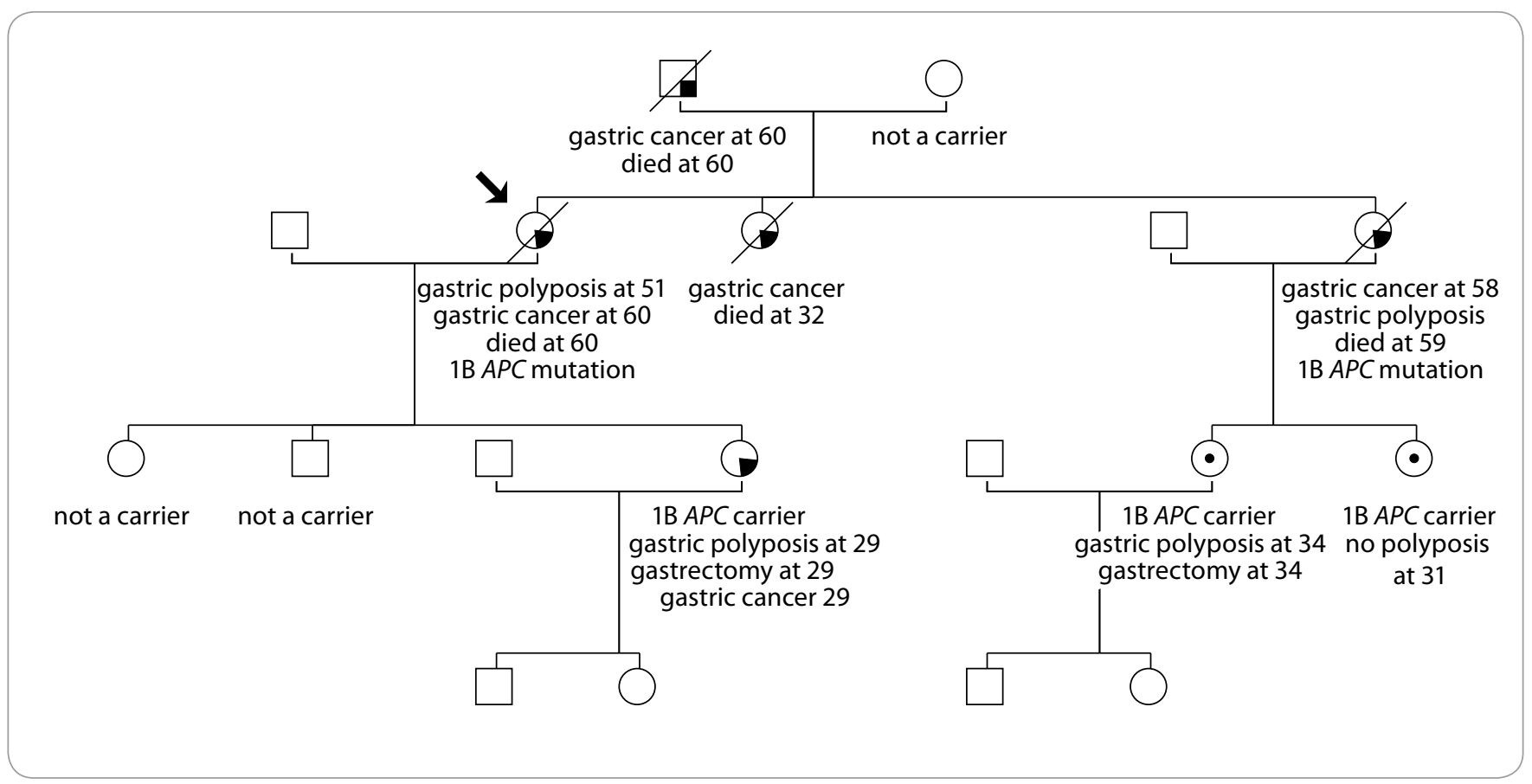

Fig. 2. Pedigree of family no. 2 (Masaryk Memorial Cancer Institute). 


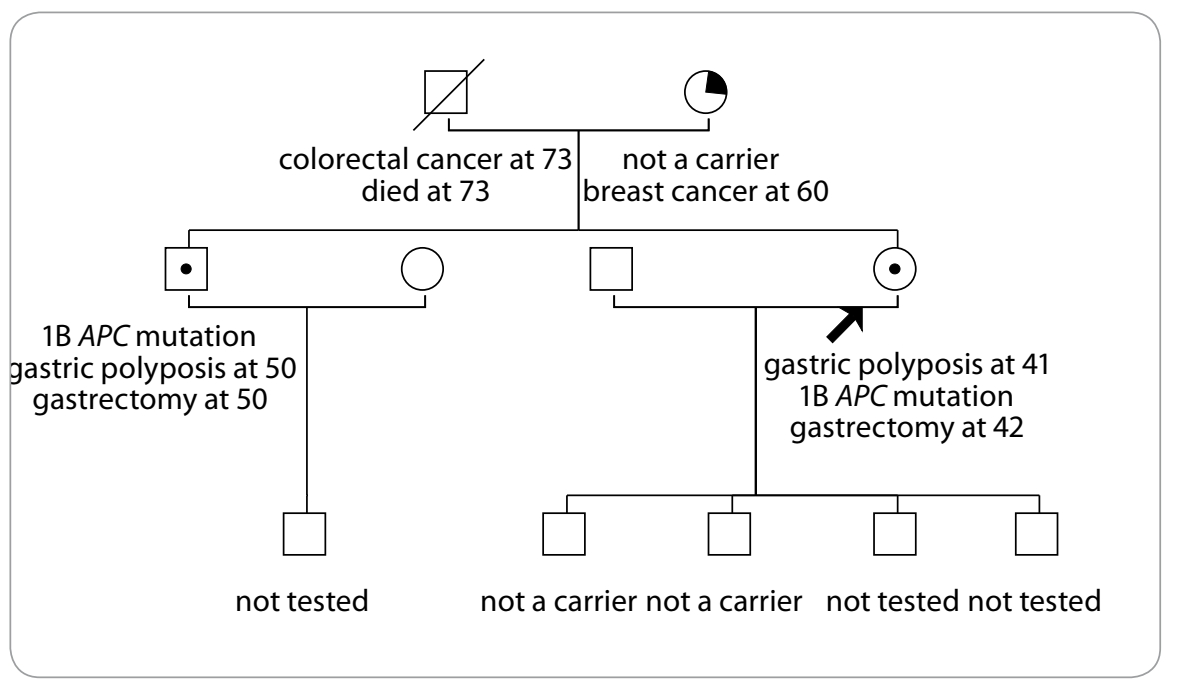

Fig. 3. Pedigree of family no. 3 (Masaryk Memorial Cancer Institute).

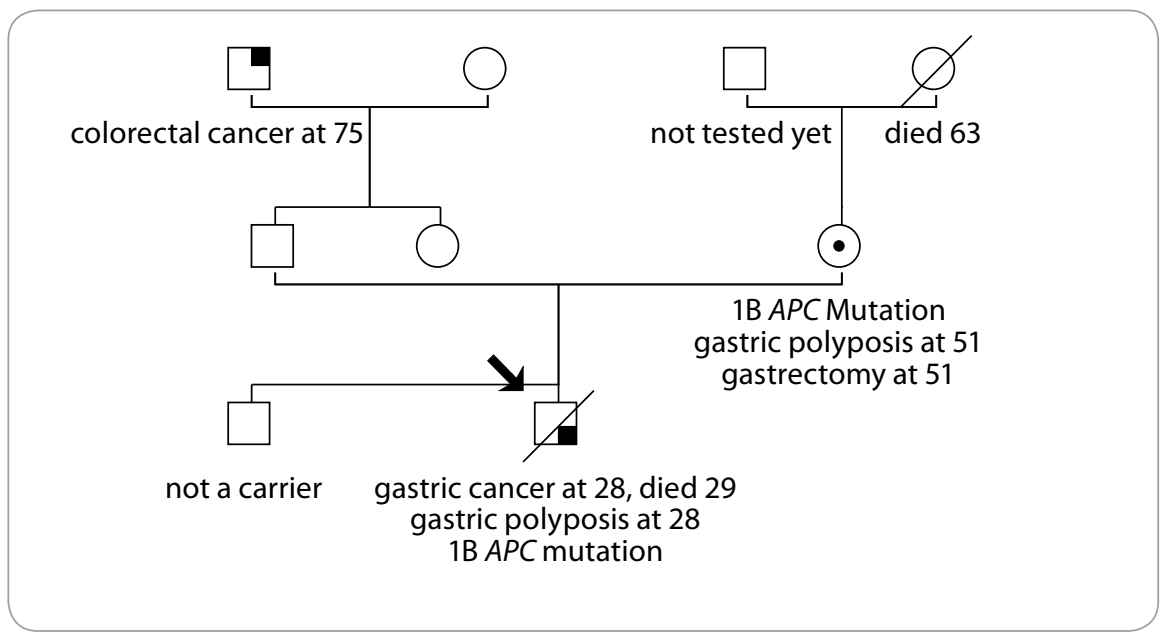

Fig. 4. Pedigree of family no. 4 (Masaryk Memorial Cancer Institute).

using PPI for 6 months. The colonoscopy was negative. Genetic testing confirmed for both APC mutation: c.-191T>C. The son is being monitored in the preventive oncology department of the $\mathrm{MMCl}$, considering preventive surgery.

Family 2 (Fig. 2)

An index case was monitored for gastric polyposis from the age of 51 outside the $\mathrm{MMCl}$. At the age of 60 , gastric adenocarcinoma with liver metastasis was detected; she died within 6 months. The colonoscopy was negative. Her sister died of gastric cancer at age 32. Another sister did not go to preventive gastroscopy, she was diagnosed with massive gastric polyposis at the age of 58 with metastatic gastric adenocarcinoma; she died a year
She is a carrier of $A P C$ mutation: c.$191 \mathrm{~T}>\mathrm{C}$. Her brother is also a carrier. He had a gastroscopy in 2018 when massive polyposis was diagnosed. A prophylactic gastrectomy with D1 lymphadenectomy was performed in both patients at University Hospital Brno, with no gastric cancer found. Two sons of the index case did not inherit the mutation. The mother of the index case was diagnosed with breast cancer and adenoma of the rectum at 60 , the gastroscopy was negative, she is not a carrier. The index case's father died of metastatic colorectal cancer at the age of 73 .

\section{Family 4 (Fig. 4)}

An index case was diagnosed with gastric tubular adenocarcinoma at the age of 28, gastric polyposis was described, he died 10 months later. Sequencing of the $1 B$ APC gene promoter detected the C.-191T>C mutation. The same mutation was detected in his mother. She did not have any clinical problems but was found to have massive polyposis at the age of 50. A prophylactic gastrectomy with D2 lymphadenectomy was performed at the age of 51, with no carcinoma found. She had one polyp on colonoscopy. Her father has not been tested yet. The index case's brother does not have the mutation.

\section{Family 5 (Fig. 5)}

The index case experienced digestive problems, pain and fatigue at 40 . She was diagnosed with massive gastric polyposis of the body and fundus with liver metastasis of gastric adenocarcinoma. Sequencing of the APC gene promoter $1 \mathrm{~B}$ revealed the mutation c.-191T>C. She died after 7 months of treatment. Her daughter carries the same mutation, the second daughter is not a carrier. The index case's mother is a carrier of the 1B APC gene: C.-191T >C, at the age of 65 she has no symptoms and no polyposis. The mother's brother died at 63 years of age of stomach cancer, he was not tested; his son and daughter do not carry the APC gene mutation. The mother's sister has a mutation of the 1B APC gene: $\mathrm{C} .-191 \mathrm{~T}>\mathrm{C}$, she has incipient gastric polyposis at the age of 58 , her son and daughter have had gastric 


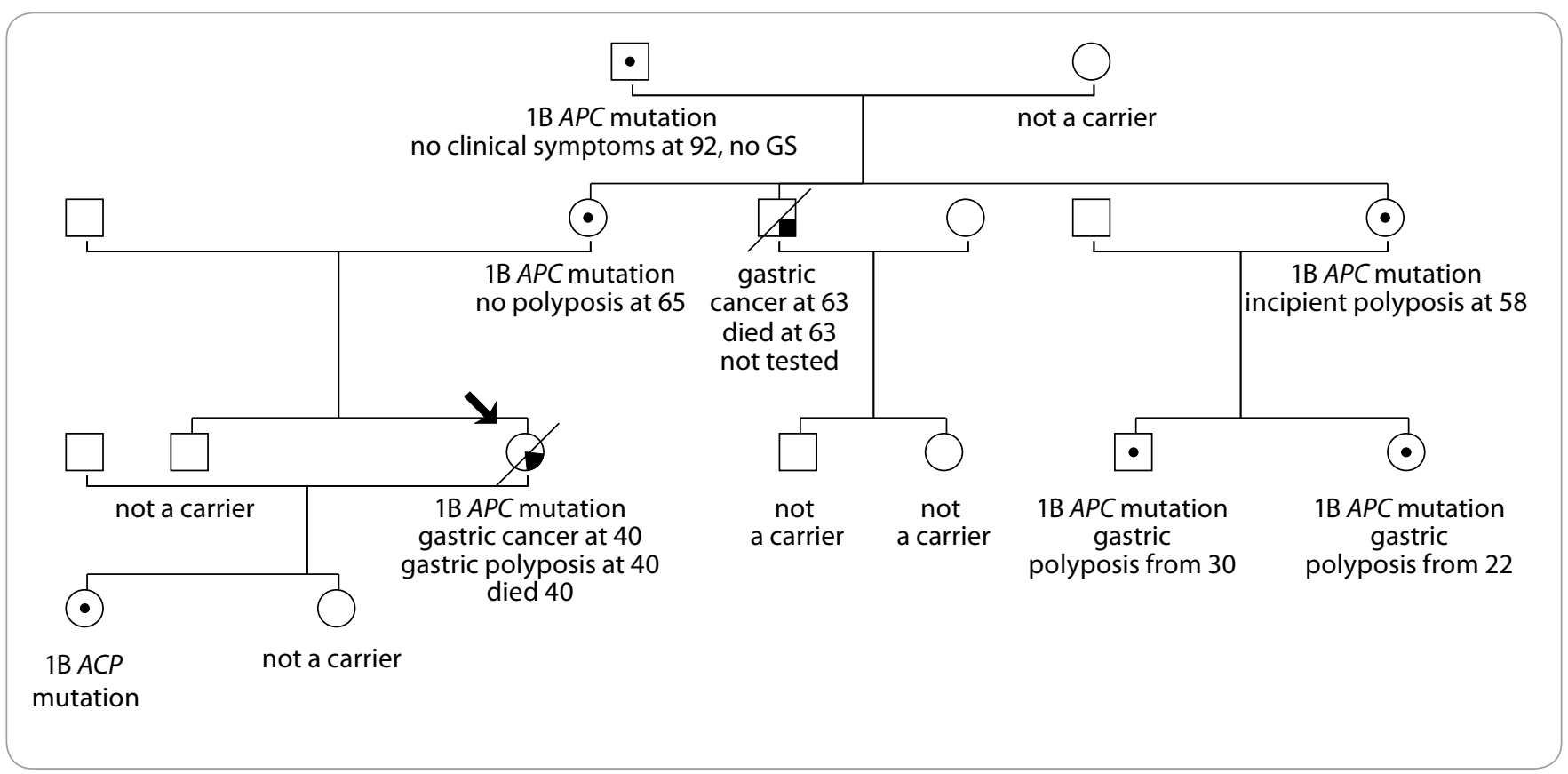

Fig. 5. Pedigree of family no. 5 (Masaryk Memorial Cancer Institute).

polyposis diagnosed at 30 and 22 years of age, respectively, both with a mutation of the 1B APC gene: c.-191T>C. A gastrectomy was recommended but has not yet been performed. The father of the mother's mother is free of clinical symptoms, he is a carrier of a mutation of the 1B APC gene: c.-191T>C. He did not have an endoscopy because of the age limitation. The index case's brother has no presence of polyps and does not carry the mutation.

\section{Family 6 (Fig. 6)}

The index case had a gastroscopy at 49 years of age for digestive problems, without pathology. At the age of 65 , she was found to have massive stomach polyposis, mutation of the $1 \mathrm{~B} A P C$ gene: c.-191T $>C$ was detected. She had a gastrectomy at the age of 65 with no cancer. One polyp was observed in a colonoscopy. Mutation of the 1B APC gene: C.-191T>C was found in her daughter and multiple stomach polyposis was detected. Preventive surgery has not yet been performed. Another daughter does not carry the mutation.

\section{Family 7 (Fig. 7)}

The index case had a gastroscopy due to digestive problems at the age of 27 . Massive stomach polyposis was de-

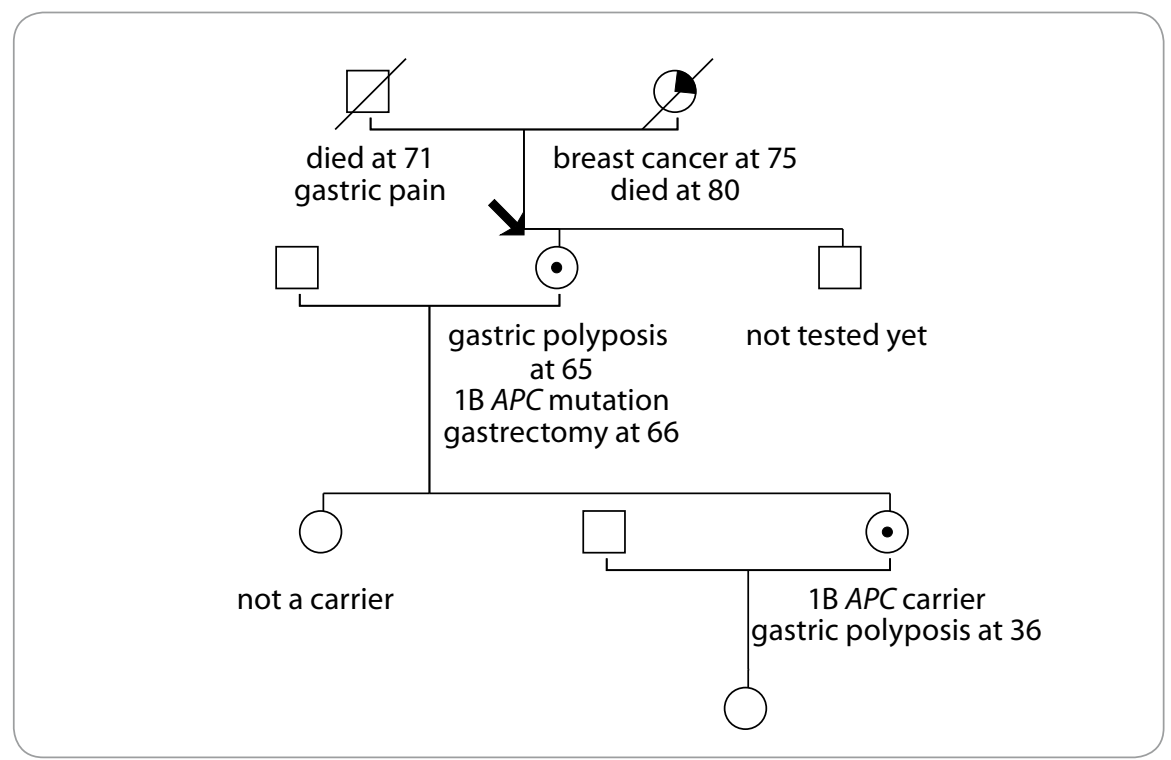

Fig. 6. Pedigree of family no. 6 (Masaryk Memorial Cancer Institute).

tected, two polyps were detected in the rectosigmoideum. A 1B APC gene mutation: C.-191T>C was detected. Now he is post gastrectomy, without cancer. The family history shows no oncological illness. His mother and two sisters do not carry the mutation; his father has not been tested yet.

Family 8 (Fig. 8)

The index case had gastroscopy due to stomach pain at 34 and multiple stom- ach polyposis was discovered. He was found to be a carrier of the $1 \mathrm{~B} A P C$ gene mutation: C.-191T>C. He has four intestinal polyps. At the age of 44 a gastrectomy was performed with no carcinoma detected. His one brother is also a carrier of the mutation, the endoscopy revealed gastric polyposis, he has no clinical problems. His father had gastric cancer at the age of 56 , with no polyposis of the stomach described; he does not carry the mutation. The mother tested positive and 


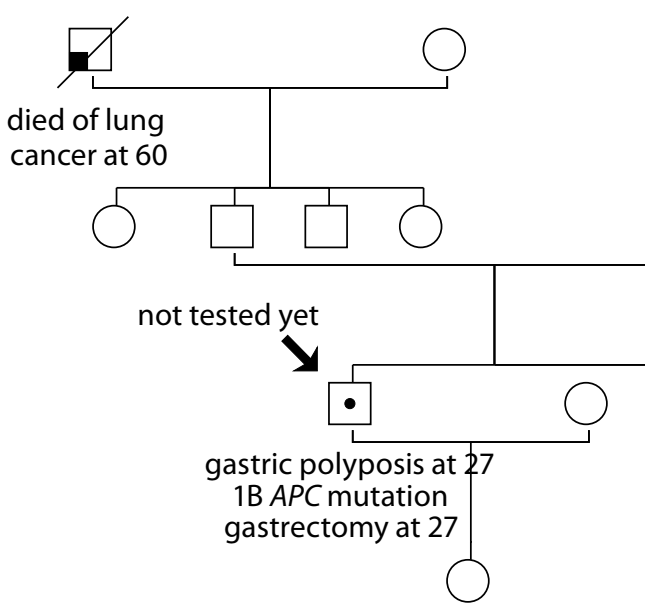

not tested

Fig. 7. Pedigree of family no. 7 (Masaryk Memorial Cancer Institute).

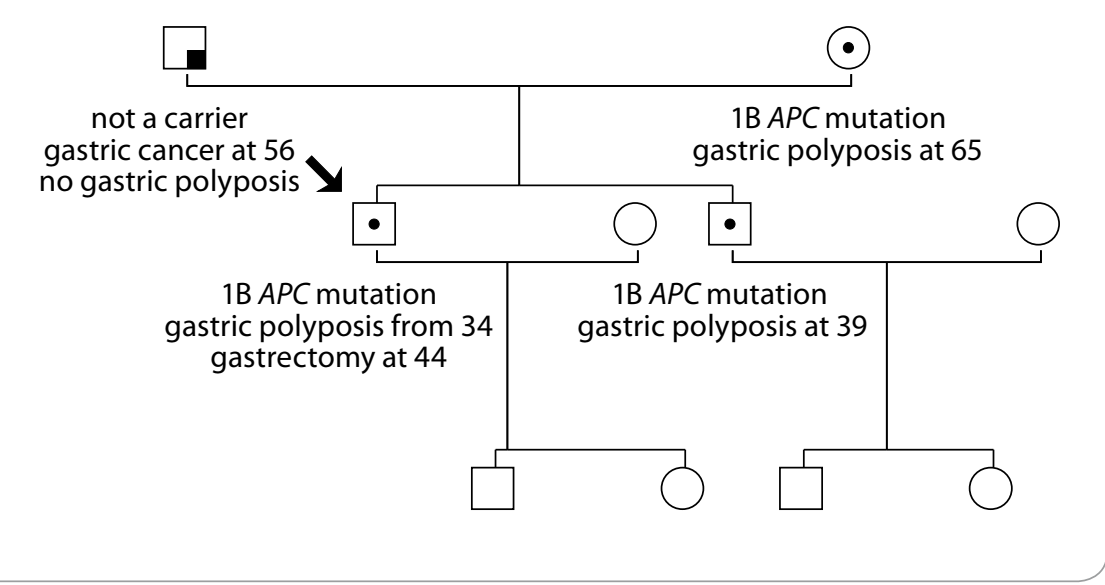

Fig. 8. Pedigree of family no. 8 (Masaryk Memorial Cancer Institute).

was diagnosed with gastric polyposis at the age of 65 .

\section{Discussion}

GAPPS syndrome is an autosomal dominant inherited disease, a variant of FAP with a high risk of massive polyposis of the stomach, with the presence of mainly glandular polyps in the body and fundus, without the presence of polyps in the antrum and duodenum (Fig. 9). Sometimes, adenomatous and hyperplastic polyps may also be present. The age of occurrence of polyposis is highly individual and depends on various factors, including genetic background, lifestyle and environment. When polypo- sis develops, the risk of gastric cancer may be high, up to $12-20 \%[1,2]$. Out of our 24 carriers of the promoter $1 \mathrm{~B} A P C$ gene mutation: c.-191T>C, 6 carriers (25\%) were diagnosed with gastric cancer. From the data provided by the families that have been tested so far, it can be seen that the variability of the symptoms of massive polyposis is very high within one family. In Family 5, the earliest polyposis was detected at the age of 22 and gastric cancer at age of 40 , but in other carriers of the mutation, polyposis was not developed at the age of 65 or it began to develop at the age of 58; in one carrier (aged 92) there were no clinical problems (no endoscopy was performed). The prediction of the development of polyposis is therefore problematic, and the prevention of gastric carcinoma by endoscopy in the field of massive polyposis is basically impossible. By discovering the genetic cause of GAPPS syndrome, point mutations in the $A P C 1 \mathrm{~B}$ promoter, it is possible to offer genetic testing to patients with stomach polyposis and to their relatives.

Genetic testing of the APC 1B promoter is performed by Sanger sequencing of the entire promoter region. Point changes are confirmed by another method on a newly isolated DNA sample (Fig. 10).

Genetic counselling is important in the process of the genetic testing of polyposis. Based on all gastroenterological, histological and family history data, the geneticist can provide additional molecular genetic examinations to elucidate the cause of polyposis. For cases with no mutation detected in the APC $1 \mathrm{~B}$ promoter, it is important to indicate further examinations that would allow the diagnosis of rare forms of hereditary tumour syndromes where gastric polyposis may be present. In the case of those who test negative, NGS (new generation sequencing, massive parallel sequencing) is appropriate. At the $\mathrm{MMCl}$, we use a panel of 226 genes that includes an examination of all known genes for polyposis syndromes as well as other hereditary tumour syndromes including other genes involved in the DNA repair process. It is, therefore, possible to diagnose classical FAP, Lynch syndrome, juvenile polyposis, Peutz-Jeghers syndrome, hereditary diffuse gastric cancer, Cowden syndrome, MYH-associated polyposis with a variable risk of stomach tumours, and rare genes where gastric polyposis may also be present.

In addition, the geneticist should recommend predictive family testing for all relatives at potential risk of carrying the same mutation. For GAPPS syndrome, this predictive test is very important because a large proportion of the relatives do not have any clinical problems for a long time, even though massive stomach polyposis may have already developed. Since the transition from dysplasia to gastric cancer in GAPPS can be 


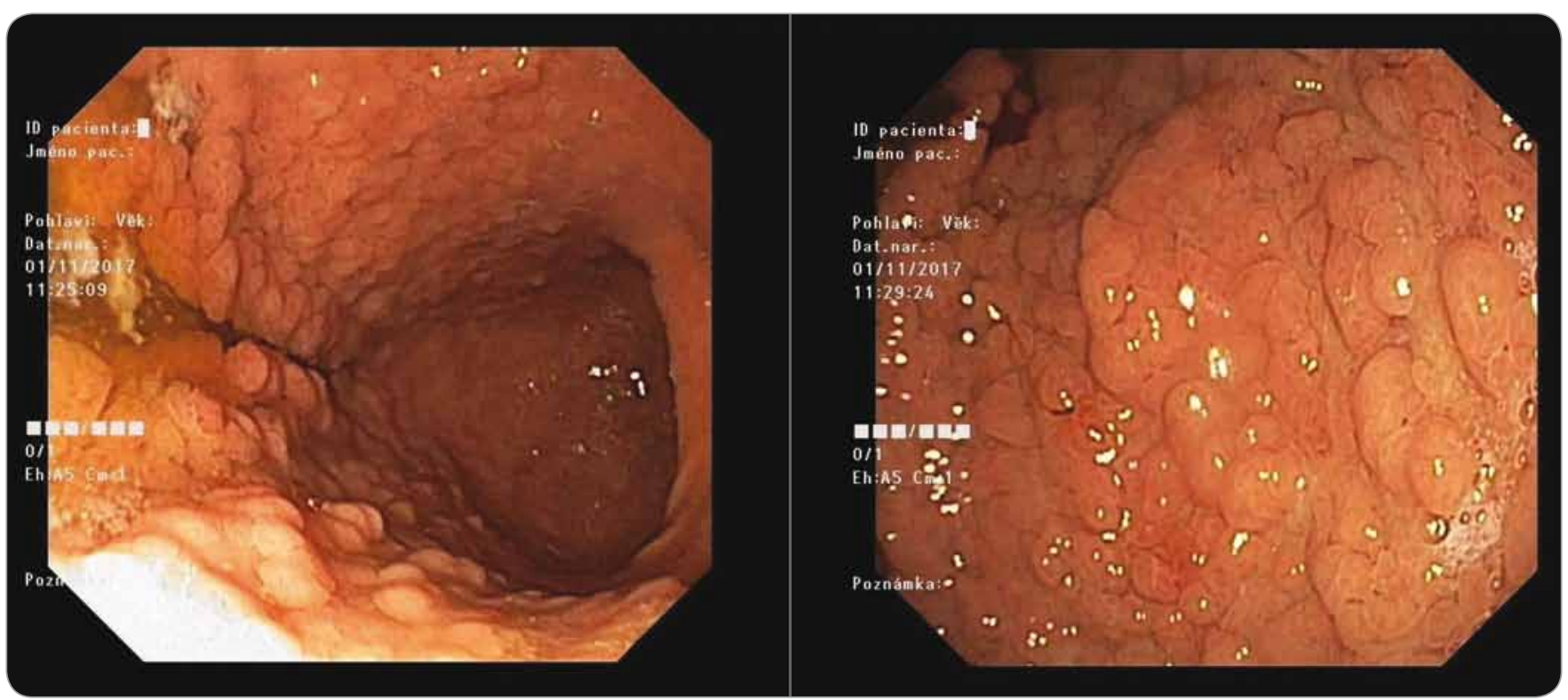

Fig. 9. Gastroscopy with massive polyposis of stomach in gastric adenocarcinoma and proximal polyposis of the stomach patient (Masaryk Memorial Cancer Institute).

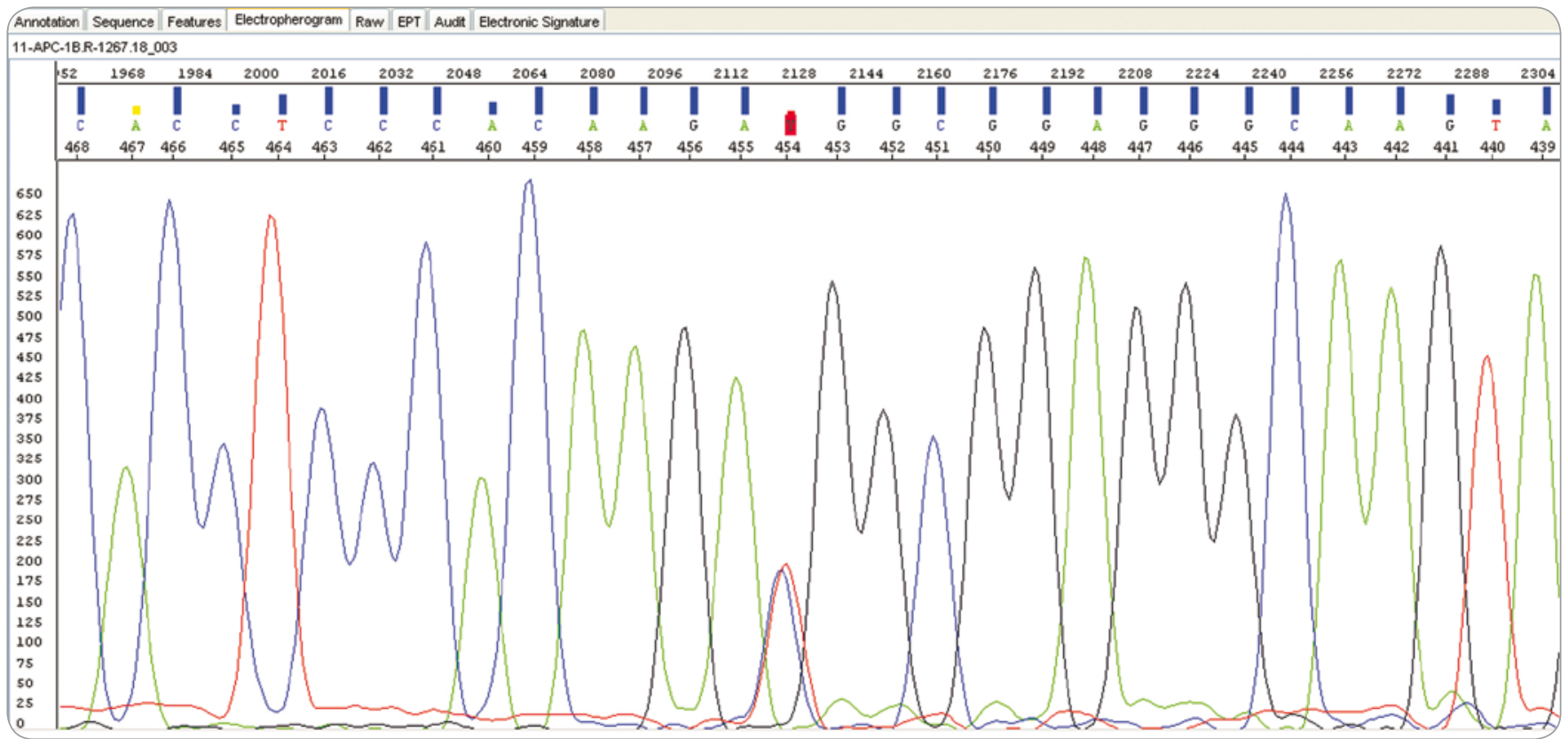

Fig. 10. Sanger sequencing: APC NM_001127511.2: C.-191T>C (Masaryk Memorial Cancer Institute).

very rapid, attempting to prevent stomach cancer in patients with GAPPS is problematic. This fact is also documented by our very first prophylactic gastrectomy with D2 lymphadenectomy performed at GAPPS at $\mathrm{MMCl}$, when a young woman 29 years of age had a G2 well-to-moderately differentiated tubulopapillary adenocarcinoma of the stomach, with positive lymphonodes, clinical stage IB, with invasion into the submucosa and angio- graphic invasion. The tumour was not detected in the gastroscopy. She underwent systemic treatment. Predictive testing was offered by another genetic clinic to two children, aged 10 and 7, respectively. There are no guidelines about predictive testing in children.

In $\mathrm{MMCl}$, prophylactic total gastrectomy (Fig. 11) with D2 lymphadenectomy is performed in patients with GAPPS and massive polyposis. Lym- phadenectomy in this range (first and second peri-gastric compartment) is the therapeutic standard in epithelial stomach malignancies and is recommended in GAPPS due to the relatively high risk of preoperatively undiagnosed carcinoma. In workplaces that specialise in stomach operations, D2 lymphadenectomy does not significantly prolong surgical time nor significantly increase postoperative morbidity (Fig. 12). 


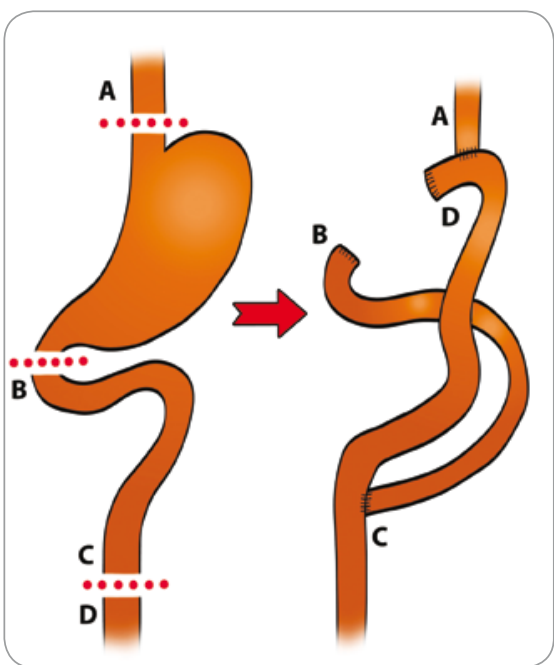

Fig. 11. Gastric adenocarcinoma and proximal polyposis of the stomach - total gastrectomy with subsequent reconstruction of the digestive tract (Masaryk Memorial Cancer Institute).

From current knowledge, it is advisable to provide genetic testing of GAPPS for these clinical findings and family history.

\section{Suggested indications for GAPPS \\ syndrome testing $[1,2]$}

- more than $30 \mathrm{FGP}$, localisation in the fundus and body, no presence in the antrum or duodenum, with or without dysplasia, the progression of polyposis, autosomal dominant inheritance stomach polyposis or stomach cancer in family history (in $1^{\text {st }}, 2^{\text {nd }}$ or $3^{\text {rd }}$ degree relatives);

- more than 100 FGP in the same location - testing with or without a family history.

If the GAPPS testing is negative, then exclude other possible syndromes with polyposis.

Differential diagnosis:

- sporadic FGP - fewer polyps, mostly without dysplasia, probably without increased tumour risk, often associated with PPI use (slightly reduced on withdrawal);

- FAP, atenuated FAP - colon polyposis, some cases with stomach polyposis, also in the antrum, pylorus and duodenum, low-grade dysplasia, low risk of stomach cancer (about 1\%);

- MAP (MUTYH) associated polyposis autosomal recessive;

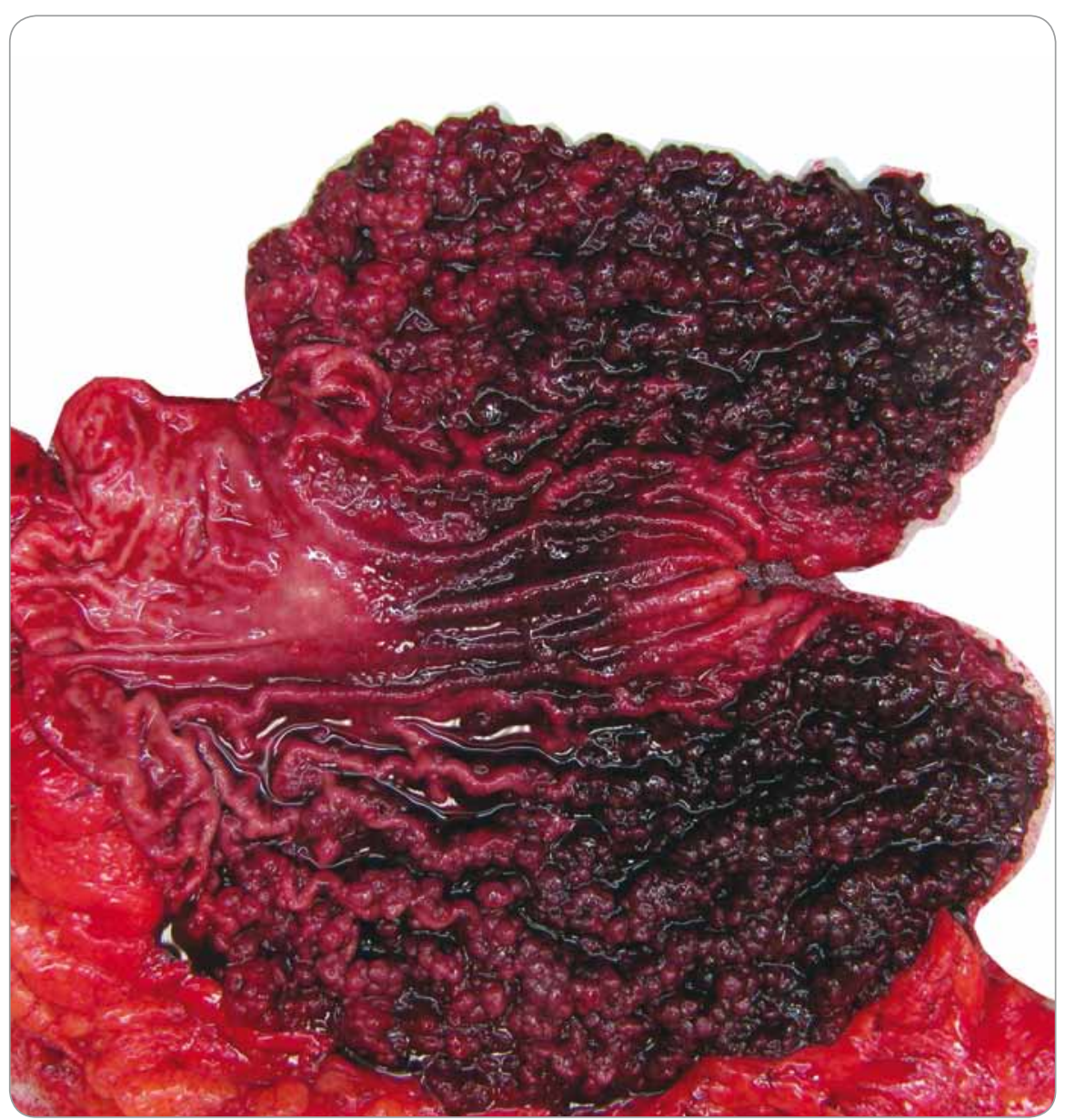

Fig. 12. Gastric adenocarcinoma and proximal polyposis of the stomach - stomach resection along with omentum (Masaryk Memorial Cancer Institute).

- juvenile polyposis - SMAD4, BMPR1A;

- Peutz-Jeghers syndrome - STK11;

- Cowden's syndrome - PTEN;

- hereditary diffuse gastric cancer - $\mathrm{CDH} 1$

- Ménétrier's disease - acquired, premalignant, massive mucosal scarring, excessive mucus production, protein loss, weak acid production.

Proposed scheme of preventive care for people with GAPPS syndrome In GAPPS with massive polyposis: - gastroscopy every year (even in the case of undeveloped polyposis), comprehensive monitoring in the risk oncology clinic;

- colonoscopy every 3 years, if polyps, more frequently;

- ultrasound of abdominal organs every year;

- when progressive massive stomach polyposis (even without polyps dysplasia, regardless of family his- tory) offer prophylactic gastrectomy that can prevent death from gastric cancer;

- as a resection, we recommend total gastrectomy with D2 lymphadenectomy;

- if the prophylactic gastrectomy is refused, then a gastroscopy every 6 months, including endoscopic removal of larger polyps for biopsy specimen, endosonography, but the risk of gastric cancer cannot be reduced, reassessment of gastrectomy in case of dysplasia;

- further monitoring at a risk oncology clinic as with other inherited tumour syndromes.

\section{Conclusion}

GAPPS, gastric adenocarcinoma and multiple proximal polyposis of the stomach syndrome, although it is referred to as a very rare variant of FAP, was found within 1 year in eight families 
with genetically confirmed GAPPS syndrome with mutation in the $A P C$ gene promoter 1B: c.-191T> C in 24 positive mutation carriers. The development of massive polyposis with fundic glandular polyps was variable, with the earliest finding at the age of 22 , with a negative finding in a woman aged 65 and no clinical symptoms in a man 92 years old. In massive polyposis, a prophylactic total gastrectomy has always been proposed. Out of a total of eight performed operations, in one case, gastric adenocarcinoma was present in a 29-year-old woman in a histological specimen. For positive carriers of promoter 1B mutation with massive polyposis, a decision on a preventive gastrectomy is also influenced by the family history and previous death in the family to stomach cancer. However, some patients based their decision solely on the basis of our information concerning cancer risk and ineffective prevention by endoscopic methods. After surgery, they are all supervised by surgeons, nutrition specialists, oncologists and gastroenterologists. In all cases, surgery was suc- cessful without serious postoperative complications.

Genetic testing for GAPPS syndrome is based on sequencing of promoter $1 \mathrm{~B}$ of the APC gene using the Sanger sequencing method, because this region is mostly not included in the NGS panel. In massive polyposis and a negative testing result, differential diagnosis of other possible genetic causes of stomach polyposis using the NGS panel is appropriate.

Preventive measures for GAPPS are individual, based on clinical symptoms; they include a gastroscopy every 6-12 months, biopsy of polyps and above all, the suggestion of a prophylactic resection of the stomach. The risk of stomach cancer in GAPPS is many times higher than that of classic FAP with FGP (< $1 \%$ and $12-20 \%$, respectively; $25 \%$ in our carriers). Due to the possibility of saving the lives of patients with GAPPS, we recommend genetic testing for multiple stomach FGP. Most of the patients relatives who tested positive had already had massive stomach polyposis and did not know it.

\section{Literature}

1. Worthley DL, Phillips KD, Wayte $N$ et al. Gastric adenocarcinoma and proximal polyposis of the stomach (GAPPS): a new autosomal dominant syndrome. Gut 2012; 61 (5): 774-779. doi: 10.1136/gutjnl-2011-300348.

2. Setia N, Clark JW, Duda DG et al. Familial gastric cancer. Oncologist 2015; 20(12): 1365-1377. doi: 10.1634/theoncologist.2015-0205.

3. Boland $C R$, Yurgelun MB. Historical perspective on familial gastric cancer. Cell Mol Gastroenterol Hepatol 2017; 3(2): 192-200. doi: 10.1016/j.jcmgh.2016.12.003.

4. Li J, Woods SL, Healey S et al. Point mutations in exon $1 B$ of APC reveal gastric adenocarcinoma and proximal polyposis of the stomach as a familial adenomatous polyposis variant. Am J Hum Genet 2016; 98(5): 830-842. doi: 10.1016/j.ajhg.2016.03.001.

5. Repak R, Kohoutova D, Podhola M et al. The first European family with gastric adenocarcinoma and proximal polyposis of the stomach: case report and review of the literature. Gastrointest Endosc 2016; 84(4): 718-725. doi: 10.1016/j.gie.2016.06.023

6. Beer A., Streubel B, Asari R et al. Gastric adenocarcinoma and proximal polyposis of the stomach (GAPPS) a rare recently described gastric polyposis syndrome - report case. Z Gastroenterol 2017; 55(11): 1131-1134. doi: 10.1055/s-0043-117182.

7. Mitsui Y, Yokoyama R, Fujimoto $S$ et al. First report of an Asian family with gastric adenocarcinoma and proximal polyposis of stomach (GAPPS) revealed with the germline mutation of the APC exon 1B promoter region. Gastric Cancer 2018; 21(6): 1058-1063. doi: 10.1007/s10120-0180855-5.

8. Hosoya K, Yamashita S, Ando T et al. Adenomatous polyposis coli $1 \mathrm{~A}$ is likely to be methylated as a passenger in human gastric carcinogenesis. Cancer Lett 2009; 285(2): 182-189. doi: 10.1016/j.canlet.2009.05.016. 